\title{
4
}

\section{Nature, Spontaneity, and Voluntary Action in Lucretius}

\author{
Monte Ransome Johnson
}

In twenty passages located throughout De rerum natura $(D R N),{ }^{1}$ Lucretius refers to natural things that are spontaneous or automatic (sponte sua; ${ }^{2}$ the Greek term is automaton). The concept is vital to Lucretius' Epicurean physics, biology, psychology, ethics, and politics, from the starting points of his cosmology through his account of free and voluntary human action: in his discussion of the powers of nature and matter; of the origin of the cosmos; of the generation and adaptation of plants and animals; and of the capacities and behaviour of human beings, including the development of human culture.

In this chapter I argue that Lucretius uses the term univocally throughout the poem, making implicit, and occasionally explicit, use of its political connotations even in the context of natural philosophy, something he is well known to do with other concepts borrowed from the political and legal lexicon. Further, I argue that

I would like to thank, first of all, the organizers of the conference in Manchester, as well as the audiences of my talk there and in the Classics department at the University of California, Irvine. I am especially grateful to those who gave me comments, criticisms, and suggestions: Daryn Lehoux, Andrew Morrison, David Konstan, Jim Hankinson (in Manchester), and Jim Porter, Zina Giannopoulou, and Kourtney Murrey (in Irvine).

${ }^{1}$ Lucr. 1.214, 1064; 2.193, 1059, 1092, 1158; 3.33, 1041; 4.47, 131, 481, 736; 5.79, $212,804,872,938,961,1147 ; 6.1021$.

2 As Bailey (1947: 96) points out, Lucretius frequently reinforces the expression, as with ipsa sponte sua at Lucr. 2.508, 1158, and 3.1041, even adding to this per se in 2.1090-2. Although Bailey considers this to be 'somewhat otiose', I would argue that the emphasis, particularly in the passage at $2.1090-2$, is meant to call attention to the importance of spontaneity to Lucretius' philosophy. 
his extensive use of spontaneity, even in the context of human action, does not commit him or Epicureanism to accidental, contingent, indeterminate, or random causes (as has been alleged from at least the time of Cicero right down to contemporary interpreters), but rather to natural and necessary ones. I argue that understanding how this is so in a variety of natural scientific contexts provides important illumination with which to read the controversial passage about the 'swerve' of atoms that causes both whole worlds and the voluntary actions of animals, including humans.

I begin with Lucretius' account of the causes of the atoms moving in the void, and how they spontaneously coalesce to form the elemental and other complex bodies. Living things are described as spontaneously generated through a similar process; and their continual existence involves a spontaneous exercise of their natural powers. The reliability of perception is described as spontaneous, even though the causes of some optical illusions are said to be spontaneous. The behaviour of early humans is described as spontaneous, as is their later submission to law and civilization. Finally, even individual human actions are described by Lucretius as spontaneous. At each level of complexity, beginning with the atomic level, natural things are understood to have different powers that they exercise spontaneously. What is stressed throughout all these cases is a lack of external influence, control, or domination.

A major influence on Lucretius' use of spontaneity, immediately or via Epicurus, is Democritus, who himself stressed that natural things happen 'of their own accord' and are 'self-driven', as opposed to operating under the influence of external causes, forces, and influences. For example, spontaneity is frequently used to describe streams and rivers that flow and flood not through planned irrigation but spontaneously; plants that grow not as a result of agriculture but spontaneously, as in the wild; of animals such as horses that move not at the direction of a human rider but of their own accord; and of humans acting not under compulsion or force but voluntarily. Democritus had argued that the fundamental causes of the cosmos, nature, living things, and free human behaviour are spontaneous, and, just as there is no external cause of the cosmos as a whole, such as the gods, so there is no overpowering external cause of human action, such as chance or fate. ${ }^{3}$ 
Later critics of Democritean and Epicurean philosophy conflated spontaneity with chance or luck, and this is largely the reason that atomists, including Lucretius, have been accused throughout history of making chance and luck the causes of everything. Epicurus' or Lucretius' discussion of the 'swerve' did not help matters with either the ancient or modern critics. But through a study of their use of the concept of spontaneity, one can see that what the atomists are committed to is not lack of order or violation of law, but rather lack of external constraint or control and domination.

Recent interpretations of Lucretius have shown that political terminology is a key to Lucretius' philosophy of nature. These studies demonstrate how thoroughly cosmological and political notions interpenetrate throughout Lucretius' work. Such political and legal concepts include 'law' (lex), 'treaty' (foedus), 'boundary' (terminus), 'compact' (depactus), and so forth, including early if not the earliest references to natural laws or laws of nature. ${ }^{4}$ I am concerned here with a related political concept that operates in conjunction with these notions, but at the same time runs to some extent in the other direction, as can be seen in a famous passage in book 2 , often read as a kind of slogan of the whole work:

quae bene cognita si teneas, natura uidetur

libera continuo, dominis priuata superbis

ipsa sua per se sponte omnia dis agere expers. (Lucr. 2.1090-2)

Once you obtain a firm grasp of these facts, you see that nature is her own mistress and is exempt from the oppression of arrogant despots, accomplishing everything by herself spontaneously [ipsa sua per se sponte] and independently and free from the jurisdiction of the gods. (trans. Smith)

In a political sense, spontaneity is a conceptual antonym to legal oppression, domination, or servitude. While the other cases of Lucretius' political terminology and imagery show that nature abides by laws, treaties, compacts, boundaries, and so forth, in this passage the idea is that nature is exempt and independent and free of a certain kind of political constraint. ${ }^{5}$

4 The most useful of these studies for me have been De Lacy (1969), Long (1977), Lehoux (2006), and Asmis (2008); see also Kennedy, this volume, Chapter 2.

5 Asmis (2008: 147) uses this passage as evidence of the general point that Lucretius uses political terminology in his physics: 'using the language of politics, Lucretius expels the gods from the domain of nature.' But in this passage Lucretius does not 'expel' the gods but rather asserts nature's 'independence' from their 
Laws and pacts, in the literal sense, are externally imposed constraints instituted by intelligent beings, whether gods or men. This is why the concepts of 'natural law' and 'laws of nature' are so paradoxical and problematic, the more so the farther back into philosophical history one looks. Lucretius for his part goes to great lengths to stress that nature is not subject to divine institutes (much less human laws), but is on the contrary 'independent and free from the jurisdiction of the gods', and this is key to his criticism of intelligent-design creationism, anthropocentrism, and anthropomorphism (Lucr. 2.10901104; cf. 5.156-234, 6.379-422). In order to express his positive naturalistic views-for example, when he is talking about the ways that plants and animals are generated-Lucretius employs the concept of spontaneity.

That natural things happen spontaneously does not require nature to be random or fail to behave in a law-like, regular, or consistent way. Just as one may voluntarily act in a way that conforms to laws, even though one is not consciously intending to obey laws, so nature might of its own accord operate in ways that conform to law-like regularities. The point about how one may obey a law spontaneously is reported by Cicero to have been made by Xenocrates of Chalcedon: 'when asked what his disciples learned, he is said to have replied: "to do spontaneously [sua sponte] what they are compelled to do by the law"' (Rep. 1.2.3, trans. Keyes, adapted). Lucretius, then, can argue both that nature is free from the jurisdiction of the gods, and that it spontaneously abides by certain laws, treaties, compacts, and so forth. All of this is so far metaphorical, of course, since inanimate objects cannot literally obey laws or follow the institutes and commands of gods or men. But, as we will see, Lucretius so consistently applies the concept of spontaneity to natural things that the concept attains cosmological significance on top of whatever political significance it had going back at least to Xenocrates.

The way that the term spontaneity can function in a general cosmological context like the one in which Lucretius asserted that nature acts 'spontaneously and free from the jurisdiction of the gods' can be seen in a curious passage from Theophrastus' Metaphysics, where the Peripatetic philosopher (of all people) concedes, at least 
aporetically, that the forms and shapes of natural things might ultimately have a spontaneous cause: 'the account that it is by spontaneity [tôi automatôi] and through the rotation of the whole that these things acquire certain forms or differences from one another, seems to have some plausibility' (10b20-11a1, trans. van Raalte, adapted). ${ }^{6}$ Theophrastus is probably referring to the cosmology of Democritus, according to which the motion in the cosmic 'vortex' spontaneously generates all change through a process of separation and combination of material bodies. ${ }^{7}$ Similar ideas have been expressed throughout the history of science, and even very recently. Consider, for example, two recent statements by cosmologist Stephen Hawking:

We believe that life arose spontaneously on the Earth. So it must be possible for life to appear on other suitable planets, of which there seem to be a large number in the galaxy. But we don't know how life first appeared. The probability of something as complicated as a DNA molecule being formed by random collisions of atoms in oceans seems incredibly small. However, there may have been some simpler macromolecule which was a building block for DNA or another molecule capable of reproducing itself. Even if the probability of life spontaneously appearing on a suitable planet is very small, since the universe is infinite, life most likely would have appeared somewhere else too. ${ }^{8}$

${ }^{6}$ On the crucial influence of Theophrastus upon Epicurus and by extension Lucretius, see the outstandingly important study of Theophrastus in Sedley (1998: ch. 6). As he points out, 'it was primarily through Theophrastus, and not through the direct impact of Aristotle's treatises, that Aristotelianism helped shape the Epicureanism which we can read in the poem of Lucretius' (1998: 184). Following up on this, I have adduced many parallels between Lucretius' usage of spontaneity and Theophrastus', which serve as further confirmation of this thesis. It is interesting that Theophrastus to a much greater extent than Aristotle incorporates spontaneity in a positive way into his philosophy of nature, for example, in conceiving of the overall division of plants into those that are 'natural and spontaneously generated' (i.e. 'wild') versus those cultivated by agriculture and artificially generated. This can be seen in passages discussed below. See also van Raalte (1993: 532-9), who in the commentary on the passage discusses tôi automatôi in Theophrastus' botanical works.

7 This seems clear to me from Theophrastus' later reference to Democritus by name at 11b22, but Democritus is not named at 10b26-11a1 (van Raalte does not speculate about the source of the view described there). Aristotle describes essentially the same view in Physics 2.4: 'There are some who make the spontaneous the cause [aitiontai to automaton] both of this heaven and of all the worlds. For they say that spontaneously the vortex came to be and the motion which separated out and established everything in the present order' (196a24-5; cf. Cael. 283a31, 287b25, 289b21). Bailey (1947: 139-43) and most other commentators follow Simplicius, in Phys. $331.16 \mathrm{ff}$, in identifying Democritus as the target of that passage.

${ }^{8}$ Hawking (2008). 
Because there is a law like gravity, the universe can and will create itself from nothing in the manner described. Spontaneous creation is the reason there is something rather than nothing, why the universe exists, why we exist. It is not necessary to invoke God to light the blue touch paper and set the universe going. ${ }^{9}$

Modern scientists like Hawking thus speak of spontaneity in the context of the origin not only of life, but of the whole cosmos. The main idea-that it is spontaneously and due to the rotation of the cosmos (or gravitational forces, and so on), and not for the sake of anything, that natural things take on the forms that they do-is in principle similar to the position that Lucretius argues for at length.

Democritus, following the Leucippean slogan: 'All things happen for a reason and out of necessity', took necessity to be the ultimate cause of natural things. Aristotle not only affirms this but also repeatedly criticizes Democritus for having named necessity as the cause of everything. ${ }^{10}$ Despite later polemics, Democritus did not identify necessity and chance, or hold them to be somehow cosmologically equivalent; on the contrary, he banished chance as a cause, speaking instead of the natural causal intersection of independent streams of necessity, in an attempt to eliminate or reduce the power of the personifications like Luck and Fate. Natural things are generated and destroyed by processes both spontaneous and necessary. ${ }^{11}$ Spontaneity has thus long been considered fully compatible with both causal regularity and necessity. ${ }^{12}$

9 Hawking and Mlodinow (2010: 180).

10 'Democritus neglects the cause for the sake of which, leading back all the operations of nature to necessity' (Gen. an. 789b2-3; cf. Metaph. 985b5-20; Cael. 300b9-17, 301a10-11). Cf. Ps.-Plut.: 'Democritus of Abdera maintained that the universe is infinite because it was not created by anything. Further, he says that it is changeless and sets out an explicit, comprehensive account of the nature of the whole. The causes of the things that now come about have no beginning, but absolutely everything that has come about and is coming about and will come about is totally governed in advance by necessity from eternity' (Misc. 7, trans. Taylor (1999) fr. $75=$ DK 68 A 39; ed. Diels (1879: 581).

${ }^{11}$ M. R. Johnson (2009a: 18-36).

12 Thus I do not conceive of spontaneity as 'distinct from causation' and associated with chance, contingency, randomness, and indeterminacy as, for example, does A. A. Long (1977: 66-7). But this is merely a terminological difference. Long states that 'the only senses of chance... which concern us in this paper are pure contingency, strict indeterminateness, and spontaneity, since any other sense of chance is quite compatible with necessity' (p. 67). I argue that spontaneity in Democritus and Lucretius should not be understood as a kind of chance but rather as a kind of necessity, and I think this is closer to the way Democritus uses automaton and Lucretius uses sponte sua, both terms conventionally translated 'spontaneity'. 
Epicurus and Lucretius agree with Democritus that the shapes and natures of complex inanimate things and plants are spontaneously generated and destroyed through recombination of atomic bodies. But, in deploying the terminology of 'spontaneity', Lucretius speaks not only in a natural science tradition, but also a political science tradition, one that extends from Xenocrates through Cicero down to the present day. As a proposition in natural science, the result is that nature of its own accord behaves in a way that it would otherwise be compelled to do by law. Thus, in a description of the formation of our world, we are told that the atoms moved and collided 'spontaneously, fortuitously, blindly', but that the eventual result of this was a coalescence of the familiar materials and natural kinds.

cum praesertim hic sit natura factus, ut ipsa
sponte sua forte offensando semina rerum
multimodis temere incassum frustraque coacta
tandem coluerunt ea quae coniecta repente
magnarum rerum fierent exordia semper,
terrai maris et caeli generisque animantum. (Lucr. 2.1058-63)

Our world is the creation of nature: the atoms themselves collided spontaneously [sponte sua] and fortuitously, clashing together blindly, unsuccessfully, and ineffectually in a multitude of ways, until at last those atoms coalesced which, when suddenly dashed together, could always form the foundations of mighty fabrics, of earth, sea, and sky, and the family of living creatures. (trans. Smith)

And in two later summaries of his cosmology (constituting a doublet), Lucretius repeats the point. I here provide two different but equally plausible translations of the passage:

I agree with Long's overall approach, and try in this chapter to build on his thesis that Lucretius allows very little or no randomness or mere contingency in his cosmology and account of human action. I further join him, for example, in disagreeing with Bailey that 'Epicurus admitted the existence of a real contingency in nature, an element of 'chance', which at times worked in contravention of necessity' (Bailey 1928: 326; cf. Long 1977: 66). I also agree with Long (1977: 65) that 'Epicurus' restrictions on indeterminate occurrences were much tighter than De Lacy suggests'. I also agree with the thrust but not exact expression of his conclusion: 'references to chance in Epicurus and Lucretius do not imply, as many modern scholars say, that sheer contingency or spontaneous events play a part in nature along with necessity' (Long 1977: 85). I agree that the passages that mention chance do not imply that sheer contingency or spontaneous events play a part in nature along with necessity, but I do think that other passages in Lucretius do directly say that spontaneous events play a part in nature. But this assumes contexts where the contrast is clearly not between spontaneity and causality per se, but between spontaneity and external causality or constraint. 
et quoniam docui cunctarum exordia rerum

qualia sint et quam uariis distantia formis

sponte sua uolitent aeterno percita motu

quoue modo possint res ex his quaeque creari. (Lucr. 3.31-4 = 4.45-8)

I have demonstrated the nature of the primary elements of all things, the diversity of their forms, the spontaneous manner [sponte sua] in which they fly about under the impulse of incessant movement, and their ability to create everything. (trans. Smith)

I have explained the nature of the primary parts of all things, how they differ, how varied their forms, how they fly without external compulsion [sponte sua] yet driven by eternal motion, how each and every material thing can be fashioned out of these primary atoms. (Lucr. $4.45-8=3.31-4$, trans. Godwin)

Godwin's 'without external constraint' brings out better than Smith's wording the political aspect of Lucretius' insistence that the atoms move spontaneously. ${ }^{13}$ Smith himself emphasizes this aspect in a later passage, in which Lucretius argues that the senses are spontaneously able to discriminate truth and falsehood.

inuenies primis ab sensibus esse creatam notitiem ueri neque sensus posse refelli. nam maiore fide debet reperirier illud, sponte sua ueris quod possit uincere falsa.

quid maiore fide porro quam sensus haberi debet? an ab sensu falso ratio orta ualebit dicere eos contra, quae tota ab sensibus orta est? (Lucr. 4.478-84)

You will find that our conception of truth is derived ultimately from the senses, and that their evidence is unimpugnable. You see, what we need is some specially reliable standard which by its own authority [sponte sua] is able to ensure the victory of truth over falsehood. Well now, what standard can be regarded as more reliable than sensation? If the senses are false, will reason be competent to impeach them when it is itself entirely dependent upon the senses? (trans. Smith).

${ }^{13}$ Godwin (1986: 95) probably goes too far in suggesting that Lucretius is here alluding to the notion of free will with the phrase 'without compulsion ... yet driven' (ad 4.47). But his note is perceptive in realizing that there is a connection between the general concept of spontaneity at issue here and Lucretius' more specific account of spontaneous human motion (discussed below). 
Legalistic terminology pervades the passage and its continuation: we are to imagine a courtroom in which the senses plead their case against a sceptical charge coming from the intellect, a scenario originally depicted by Democritus: 'when Democritus had brought charges against the senses, saying: "by convention colour, by convention sweet, by convention bitter: in reality atoms and void", he had the senses reply to the intellect as follows: "Poor mind, do you take your evidence from us and then try to overthrow us? Our overthrow is your fall"' (Galen, On Medical Experience 15.7-8, trans. Barnes 1987). ${ }^{14}$ Smith's translation of Lucretius' sponte sua 'by its own authority' is thus justified (as is Godwin's 'independently'), and can be supported by a related argument in Cicero: 'truth and falsehood, the logical and illogical, are judged by themselves and not by anything else (sua sponte, non aliena)' (Leg. 1.17.45, trans. Keyes). The assumption is that all parties to the dispute agree that there needs to be some independent criterion of truth and falsehood. Lucretius, following Epicurus, holds that the existence of truth and falsehood depend on an independent standard by which to judge them, and that the senses are the only things that can provide that standard, since thinking requires the senses, but not vice versa. By means of the spontaneous operation of the senses, then, we must be able to distinguish truth from falsehood, or else there will be no independent standard, but, if there is no independent standard, then nothing can be proven true or false. But, if nothing can be proven true or false, then it would not be possible to prove that the senses are unreliable, and thus the argument against the senses is, from the Epicurean point of view, self-refuting.

The usage of sponte sua in this context is thus to be expected, given the framework of the debate over the criterion, and is entirely in keeping with the frequent contrast between spontaneity and external or extrinsic factors, a point that we have already touched upon and will return to below. Lucretius, however, also uses the term sponte sua in book 4 in a discussion of the causes of optical illusions. I digress in

\footnotetext{
$14=$ Democritus DK 68 B 125. Bailey fails to take notice of the parallel, and argues that, although allowing that he may have Academic sceptics in mind, Lucretius is here reiterating an argument of Epicurus' against followers of Democritus 'who exaggerated their master's semi-scepticism' (Bailey 1947: ad Lucr. 4.469). But a more straightforward interpretation of the passage is that it is a reworking (by Epicurus or Lucretius) of Democritus' own 'semi-sceptical' argument, which in the end refutes the sceptic of the senses with the defence of self-evidence and the counter-charge of self-refutation.
} 
what follows to explain how this usage remains consistent with the uses of sponte sua already discussed.

In a passage that has seemed to many commentators to be out of place (coming just after a corrupt passage and interrupting the train of thought), Lucretius asserts that images or idols are produced by being emitted not only from the surfaces of solid objects, but also spontaneously in the air. 'You must not imagine that the only images of things straying about are those that withdraw from objects. There are others that are spontaneously produced and self-created [sponte sua gignuntur et ipsa | constituuntur] in the part of the sky that is called the air' (Lucr. 4.129-33, trans. Smith). Regardless of the positioning of the passage, the argument is important enough that it is repeated by Lucretius later in the same book: 'images of every kind are moving everywhere, some formed spontaneously [sponte sua] in the air, others emanating from various things and compounded of their different shapes' (Lucr. 4.736, trans. Smith); and anyway Epicurus too held the doctrine that images are formed in the air apart from any solid body (Ep. Hdt. 48). Most commentators have interpreted Epicurus and Lucretius to be trying to account for the sociological fact that people perceive of fantastical beings like centaurs: images of men and horses are 'spontaneously' produced in the air, giving the impression that there really is a part-man, part-horse creature. But, if this is the case, and false images can be produced and conveyed to the senses spontaneously, then how can it be maintained that the senses are able spontaneously to discriminate the true from the false?

Here we reach a deep problem for Epicurean canonic that for the most part lies outside the scope of this chapter. It is an issue that Lucretius shows particular concern for, devoting a large part of book 4 to the discussion of various optical illusions and the spontaneous production of images in the air (Lucr. 4.379-468, 722-48). A standard way to cope with them, not available to an Epicurean, is to differentiate between what the senses receive (the so-called sense impression) and what the subject perceives (the 'perception'). For example, one may account for the appearance of a halo around the moon by distinguishing between how the light is refracted in the atmosphere to (or from) the eye (by saying that it is refracted in uniform particles suspended in a cloud located between the observer and the moon) and how it is perceived by an observer (as a perfect circle surrounding the moon, because the refraction is at a constant angle, resulting in every particle 22 degrees from the observer being illuminated); in this 
way one may distinguish between the causes of the sensation and the perception. But this way of accounting for the illusion then opens the doors to all sorts of sceptical attacks on the veracity of the senses based on the very possibility of a difference between what is sensed and what is perceived. Epicureans try to avoid those attacks by denying that there is in fact any difference between the sensation and the perception. Thus Epicurus asserts that the halo around the moon is a cloud that has been shaped into a circle by winds or some other movement of air (Ep. Pyth. 110-11). Although he countenances multiple explanations of such meteorological phenomena, and was probably familiar with Aristotle's explanation in the Meteorology, ${ }^{15}$ neither he nor Lucretius mentions Aristotle's account of the halo as an optical illusion. Epicurus' explanation of the lunar halo is inferior to that offered by Aristotle, who clearly understood that the appearance of the halo is not due to the shape of the cloud but is an optical illusion based on the way the course of light is altered in a cloud of small, uniform particles. ${ }^{16}$ Lucretius' explanation of the appearance of monsters and ships in the clouds adheres to the same doctrine used by Epicurus to explain phenomena like the halo: clouds spontaneously appear in the shape of a halo, a mountain, a monster, or a ship, and the sensation of a halo or ship in the atmosphere is an accurate image of what the cloud really looks like. The difficulty consists in explaining how the wind or spontaneous movements in the air could possibly cause such shapes, and on this point Lucretius makes no progress beyond or even up to Epicurus' retrograde speculations. But the important point for the present investigation is that the clouds take on these surprising forms not because of the machinations of a god (like Iris), but because of entirely natural causes. Thus, even if we think that Epicurus and Lucretius have not understood the real natural causes of these phenomena (such as refraction of light in ice crystals that act like tiny prisms), there seems to be no basis of disagreement that the causes are in fact natural and thus spontaneous in the sense in which they consistently use that term. There is no

\footnotetext{
15 See Hankinson, this volume, Chapter 3 (on evidence of Epicurus' familiarity with Ar. Meteor.); as one can see from Hankinson's convenient collation of the passages (p. 97), Lucretius fails to mention even Epicurus' explanation of the halo. Perhaps he sensed the weakness of this account vis-à-vis the Peripatetic alternative, but could not find a way to accommodate the explanation with fundamental tenets of Epicurean canonic.

16 See my discussion of this point in M. R. Johnson (2009b: esp. 331-2).
} 
contradiction between the idea that the senses are spontaneously and independently reliable, and that images of haloes and monsters and ships are spontaneously (that is, naturalistically) formed in the clouds. Again, wider issues of the viability of the Epicurean theory of sensation will be set aside here.

The passages discussed above all use the concept of spontaneity in a cosmological sense with more or less implicit reference to the political aspects of the term. But in each case, Lucretius' description of the atoms moving and colliding 'without external constraint', of the power of the senses discriminating truth and falsehood 'by their own authority', and of even illusory images in the clouds appearing 'spontaneously', all relate back to the starting point and theologicalpolitical slogan of the work, that 'nature is her own mistress and is exempt from the oppression of arrogant despots, accomplishing everything by herself spontaneously [ipsa sua per se sponte] and independently and free from the jurisdiction of the gods'. Nevertheless, Lucretius must not press the political aspect of spontaneity too far, lest, in attempting to deny divine control over natural things, he would anthropomorphically impute deliberate and intentional actions to natural bodies. ${ }^{17}$ Compare Lucretius' treatment of the spontaneous movement and collision of the atoms to his denial that the heavenly bodies move spontaneously for the sake of something, such as divine or human interests.

praeterea solis cursus lunaeque meatus expediam qua ui flectat natura gubernans, ne forte haec inter caelum terramque reamur libera sponte sua cursus lustrare perennis morigera ad fruges augendas atque animantis, neue aliqua diuom uolui ratione putemus. (Lucr. 5.76-81)

I will show by what force piloting nature steers the courses of the sun and the motions of the moon, in order to preclude the possibility of our thinking that these bodies freely and spontaneously [sponte sua] pursue their perennial courses between heaven and earth out of kindly consideration for the growth of crops and living creatures, or that they roll on by some divine design. (trans. Smith)

17 As D. P. Fowler (2002: 280) succinctly puts it: 'things happen in L. sponte sua in the sense that the gods do not cause them (2.1090-3); but the world and its constituent parts are not really animate and independent (5.78-81, 1.1021-3)'. 
Thus Lucretius takes strong exception to the kind of anthropocentric view that one finds, for example, in Socrates' teleological remarks as recollected by Xenophon, ${ }^{18}$ in Plato's Phaedo, Timaeus and Laws; ${ }^{19}$ in certain versions or interpretations of Aristotle's teleology; ${ }^{20}$ and later in Stoic views about the providential ordering of the world. ${ }^{21}$

To deny that the celestial bodies 'voluntarily' move for the sake of human beings-for example, to promote crop growth-does not at all conflict with the idea that the heavenly bodies move spontaneously in

18 Xenophon, Mem. 1.4 and 4.3. See M. R. Johnson (2005: 116-17); Sedley (2007: 75-92).

19 Plato, Phd. 98b; Ti. 48a; and Leg. 10.889b-d. See M. R. Johnson (2005: 118-27); Sedley (2007: 93-132). In a passage relating Stoic and Platonic views, Cicero makes the following comment on this kind of use of 'spontaneous': 'this intense world-heat does not derive its motion from the operation of some outside force, but is self-moved and spontaneous [sua sponte] in its activity: for how can there be anything more powerful than the world, to impart motion and activity to the warmth by which the world is held together? For let us hear Plato, that divine philosopher, for so almost he is to be deemed. He holds that motion is of two sorts, one of itself, the other from without; and that that which moves itself spontaneously [sua sponte] is more divine than that which has motion imparted to it by some force not its own' (Nat. D. 2.1112.31-2, trans. Rackham, modified). This passage is important in showing that the most important contrast with spontaneous motion is motion caused by an external source. Thus the spontaneous is not treated as causeless or indeterminate, but rather as self-caused and self-motivated.

20 According to an important and influential study by Furley (1966: 29-30), Lucretius' main target is not the Stoics, but the providential and teleological cosmology put forth by 'Platonists and Aristotelians', including several of Plato's works and the popular works of Aristotle, such as De philosophia. Furley finds support for Bignone's thesis that Epicurus formulated his arguments in opposition not to the works of our Aristotle Corpus, but to the exoteric works, such as the De philosophia (22-3). Furley has elsewhere interpreted Aristotle's Physics as being committed to anthropocentric teleology (1985: 177-82). He is followed in this by Sedley (1991: 179-96). But see my criticism of the anthropocentric interpretation in M. R. Johnson (2005: 150-8, 229-37, 271-86). This is not the place to resolve Furley's interpretation of Aristotle's De philosophia, but, even if a character in Aristotle's lost dialogue expressed a Socratic or Platonic anthropocentric teleology and kind of intelligentdesign creationism, it does not follow that Aristotle is himself committed to such a view, especially since the evidence for the De philosophia is fragmentary and may have included qualifications or criticisms not cited by Cicero; and there is strong evidence in the Corpus that Aristotle rejects, and with good reason, creationism, intelligent design, and anthropocentrism.

${ }^{21}$ Cicero's De natura deorum 2.93 states the Stoic view as against the Epicurean, invoking an argument from an exoteric work of Aristotle against it; cf. Marcus Aurelius 4.3, 9.28, 10.6. See Long (1977: 63-4 and n. 3), who remains open to the Stoics being a target of Lucretius. On Stoic teleology in general, see Sedley (2007: 205-38); for a discussion of differences between Aristotelian and Stoic teleology, see M. R. Johnson (2005: 233, 260-3). 
the sense mentioned earlier, meaning free from external constraint as by the intentional actions of the gods. Even Aristotle, who uses the same example of crop growth in a similar context in Physics 2.8, would hold the cause to be a natural one and not the intentional action of a god, even if it must be thought due to some kind of cosmic or anthropocentric teleology. Clearly Lucretius and the Epicureans at any rate reject the idea that the stars move by external constraint, such as at the direction of the gods, for the sake of either divine or human interests. A passage in Horace, making reference to Democritus and thought by some to allude to Lucretius directly, ${ }^{22}$ raises the question of stellae sponte sua iussaene uagentur et errent ('whether the stars spontaneously or under orders wander about and are erratic' (Hor., Epist. 1.12.17).

The heavenly bodies, like the familiar terrestrial elements, move spontaneously insofar as they are moved naturally. But they do not do so with deliberate intent, and their 'spontaneous' motions are constrained by certain material necessities and thus occur within certain limits, represented by Lucretius as 'pacts' and 'laws' and so forth. Lucretius uses the term spontaneously this way in connection with characterizing the view that the universe has a centre, and showing how such a view explains that terrestrial things do not fall or shoot up into the celestial region:
nec cum subsiliunt ignes ad tecta domorum
et simili ratione animalia suppa uagari
contendunt neque posse e terris in loca caeli
reccidere inferiora magis quam corpora nostra
sponte sua possint in caeli templa uolare. (Lucr. 1.1061-4)

Similarly they argue that animals roam upside down and cannot drop off the earth into the regions of the sky below any more than our bodies can spontaneously [sponta sua] shoot up into the celestial precincts. (trans. Smith, adapted)

Similarly, in his discussions of fire and magnetism, Lucretius argues that material bodies are forced or compelled to move upwards and do not do so spontaneously.

et celeri flamma degustant tigna trabesque, sponte sua facere id sine ui subiecta putandum est. (Lucr. 2.192-3)

22 That Horace here may allude to Lucretius, see D. P. Fowler (2002: 280). 
But when fires leap up to the roofs of houses and lick beams and rafters with darting flame, it must not be supposed that they do this spontaneously [sponte sua] without any external constraint. (trans. Smith)

hoc fit idem cunctas in partis: unde uacefit cumque locus, siue e transuerso siue superne, corpora continuo in uacuum uicina feruntur; quippe agitantur enim plagis aliunde, nec ipsa sponte sua sursum possunt consurgere in auras. (Lucr. 6.1017-21)

The same process may occur in any direction: wherever a vacuum is made, whether at the side of the iron or above it, the nearest particles at once move into the empty space; and they do this under the impulse of impacts from the opposite side: they cannot spontaneously [sponte sua] rise upward into the air. (trans. Smith)

The natural, spontaneous motion of material bodies is downwards, in accordance with the inner necessity of their heaviness, and so the appearance of a natural motion 'upwards' must be explained. Lucretius does so by denying that the upward motion of fire and magnets is spontaneous, describing how external forces determine their motion. Such passages support the contention that 'spontaneous' does not necessarily mean indeterminate, random, or irregular. On the contrary, the spontaneous motions of natural bodies conform to certain limits and regularities, although they do so out of their own nature and not by external constraint, such as externally imposed laws.

Many passages from ancient Greek writers can be cited to support the point. Thucydides, for example, describes 'forest fires on the mountains which have broken out spontaneously through the branches of trees being rubbed together by the wind' (2.77.4.4, trans. R. Warner). Notice that the idea is not that the fires were uncaused or random, for Thucydides gives the cause; they are spontaneous because they happen because of the collision of the trees themselves, not external agency, like lightning or clearing for agricultural purposes. Similarly, Herodotus says that the Egyptians at the Nile 'wait for the river spontaneously [automatos] to flood their fields' (2.14.2). The flooding is natural and very regular, the opposite of a 'random' occurrence. Herodotus also uses the term to explain how salt regularly crystallizes by 'natural processes' (automatoi) at the mouth of the river (4.53.3). For Aristotle, too, the waters of springs and rivers flow 'spontaneously' (Mete. 353b28). 
Thus the assertion that something happens spontaneously does not imply that it is causeless or random. The very old conception of water flowing spontaneously downwards can easily be generalized into the natural motions of the other elements, such as earth and air. Fire, as we have seen, presents a complicated case for the Epicureans, but it must be because it had been argued or assumed that spontaneity was a cause of fire's upward motion that it was necessary for the Epicureans and Lucretius to deny that fire spontaneously moves upwards. But, if the concept of spontaneity could come to be applied to the natural motion of the elements and bodies like magnets, then it can also be extended to other material bodies, such as the celestial bodies and, at the other end of the spectrum, to the atoms and 'seeds'. In what follows, we will see how the concept of spontaneity has also been applied to the generation of plants and animals.

Lucretius describes an earlier phase of earth's natural history in which abundant and luxuriant plants were spontaneously produced out of the uncultivated earth.

praeterea nitidas fruges uinetaque laeta sponte sua primum mortalibus ipsa creauit, ipsa dedit dulcis fetus et pabula laeta; quae nunc uix nostro grandescunt aucta labore. (Lucr. 2.1157-60)

Moreover, in the beginning the earth herself spontaneously [sponte sua] produced lustrous crops and exuberant vines for mortals; she herself [ipsa] gave them pleasant fruits and lush pastures, which now scarcely grow in spite of our toilsome tendance. (trans. Smith)

nec robustus erat curui moderator aratri quisquam, nec scibat ferro molirier arua nec noua defodere in terram uirgulta neque altis arboribus ueteres decidere falcibu' ramos. quod sol atque imbres dederant, quod terra crearat sponte sua, satis id placabat pectora donum. (Lucr. 5.933-8)

No sturdy farmer guided the curved plough; no one knew how to work the fields with iron implements or plant young saplings in the earth, or cut the old boughs from tall trees with pruning hooks. What the sun and rains had given them, what the earth had spontaneously [sponte sua] produced, were gifts rich enough to content their hearts. (trans. Smith)

In Diodorus of Sicily's History, we read the same Democritean account of the history of plant cultivation; the Greek term used is 
automatous. ${ }^{23}$ The idea of plant food growing without cultivation is an archaic one that can be found already in Homer's description of the race of Cyclops, who 'never use their own hands to sow or plough; yet with no sowing and no ploughing, the crops all grow for themwheat and barley and grapes that yield wine from ample clusters, swelled by the showers of Zeus' (Od. 9.106-11, trans. Shewring). More generally, we read in Hesiod that 'the fruitful earth spontaneously [automatê] bears fruit abundantly' (Op. 117-18, also 103; cf. Soph. OC 698, Pl. Leg. 4.713c4). A similar idea was elaborated in Latin poetry by Ovid: 'The golden age was sown first, which, with no punishment, of its own accord [sponte sua], without law, cultivated faith and right.... and soon the Earth, unploughed, even began to bring forth fruits' (Met. 1.90-110). Ovid's initial description of the Golden Age recalls Xenocrates' prescription for his students 'to do of their own accord [sponte sua] what they are compelled to do by the law' (Cicero, Rep. 1.2.3); nature did so in the Golden Age by producing fruit without need of plough or hoe.

Unfortunately, in the present phase of world history, food-providing plants do not spontaneously luxuriate, and so it is necessary to employ toilsome cultivation.

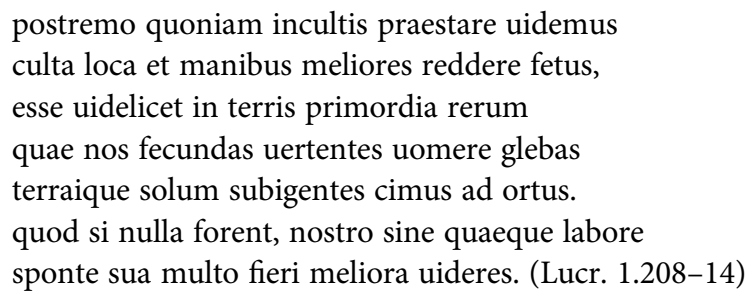

Finally, since we see that cultivated ground is superior to uncultivated and rewards the labour of our hands with improved yield, it is evident that the earth contains elements of things which we rouse from dormancy when we turn up the fertile clods with the ploughshare and trench the soil. If this were not so, our labour would be unnecessary, because you would see things everywhere improve considerably of their own accord [sponte sua]. (trans. Smith)

si non fecundas uertentes uomere glebas terraique solum subigentes cimus ad ortus, sponte sua nequeant liquidas exsistere in auras. (Lucr. 5.210-12) 
Unless, by turning up the fertile clods with the ploughshare and trenching the soil, we rouse seeds from dormancy, plants cannot spontaneously [sponte sua] emerge into the limpid air. (trans. Smith)

The opposition between spontaneous plant growth and cultivation by agriculture is used several times by Herodotus, who mentions numerous plants that grow not by cultivation but 'wild' (automata) (2.94.2; cf. $3.100 ; 4.74 ; 8.138 .2)$. Theophrastus, who as we have seen takes seriously the idea of spontaneous natural causes, divided the study of plants into the spontaneously produced ones that correspond to the 'natural', on the one hand, and, on the other hand, the cultivated and 'artificial' ones: 'these constitute two divisions of the subject, the one as it were natural and spontaneous [automaton], the other belonging to art and preparation, which intends the good. But the account is not the same for both, the first is what we might call an account from nature, the other from inventiveness, nature doing nothing in vain, and intellect proposing to help nature' (Caus. pl. 2.1.1.6-11, trans. Einarson and Link). ${ }^{24}$ The distinction was translated into Latin, as, for example, in Virgil: 'Nature, first of all, is versatile in growing trees, for some come about spontaneously [sponte sua] by themselves without being forced' (G. 2.9-11). These uses of the term spontaneity in the context of plants show, once again, that spontaneity is to be opposed not to causality and order, but to externally imposed causes and artificial inputs. We have here a long tradition of affiliating the spontaneous with the natural, and opposing these to the artificial and what is cultivated by external causes.

The concept of a spontaneous cause of plant growth is easily extended to the explanation of the origin and generation of animal life, and we can actually see this process of analogical extension in book 5 .

${ }^{24}$ Cf. 'The study of plants pursues two different investigations in two different fields. The first investigation deals with plants that grow spontaneously [automatos], and here the starting point belongs to their nature; whereas the other starting point is that which proceeds from human ingenuity and contrivance, which we assert helps their nature to achieve its goal' (Caus. pl. 3.1.1.1-5, trans. Einarson and Link; Cf. Hist. pl. 2.1.1.1-10). Theophrastus goes so far as to identify the spontaneous and the principle of nature, as opposed to art: 'the nature contains the starting points in itself, and we speak here of the natural, and what we see in plants that grow from those that are spontaneous [ek tôn automatôn] is of this description' (Caus. pl. 1.16.10.5-6). 
principio genus alituum uariaeque uolucres oua relinquebant exclusae tempore uerno, folliculos ut nunc teretes aestate cicadae linquunt sponte sua uictum uitamque petentes. tum tibi terra dedit primum mortalia saecla; multus enim calor atque umor superabat in aruis. hoc ubi quaeque loci regio opportuna dabatur, crescebant uteri terram radicibus apti; quos ubi tempore maturo patefecerat aetas infantum fugiens umorem aurasque petessens, conuertebat ibi natura foramina terrae et sucum uenis cogebat fundere apertis consimilem lactis, sicut nunc femina quaeque, cum peperit, dulci repletur lacte, quod omnis impetus in mammas conuertitur ille alimenti. (Lucr. 5.801-15)

First of all the various kinds of winged birds were hatched out of their eggs in the springtime, just as now in the summer cicadas spontaneously [sponte sua] leave their smooth chrysalises in search of a living and life. The earth, you see, first produced animals at that time because there was a great abundance of warmth and moisture on the ground. So, wherever a suitable spot offered, wombs grew up, adhering to the earth like roots; and when at the time of maturing these had been burst open by the young ones in their eagerness to escape from the moisture and obtain air, then nature directed to them the ducts of the earth and made her exude from her opened veins a milk-like juice, just as now every woman after childbirth is filled with sweet milk. (trans. Smith)

Lucretius adapts the idea of spontaneous plant growth to the generation of animals by conceiving of animals in earlier earth history as being plant-like, with roots and so forth. As with plant growth, the idea of a spontaneous cause of animal generation goes back to early Greek literature and philosophy. ${ }^{25}$ Censorinus, for example, links up the Lucretian passage with a related doctrine of Democritus. ${ }^{26}$

Democrito uero Abderitae ex aqua limoque primum uisum esse homines procreatos. Nec longe secus Epicurus: is enim credidit limo calfacto uteros

${ }^{25}$ Waszink (1964); Schrijvers (1974). A masterful treatment of Lucretius' argument and its sources is now available in Campbell (2003).

${ }^{26}$ Censorinus' source on Epicurus was probably Lucretius, to whom he refers in an earlier passage at 4.7 . 
nescio quos radicibus terrae cohaerentes primum increuisse et infantibus ex se editis ingenitum lactis umorem, natura ministrante, praebuisse, quos ita eductos et adultos genus humanum propagasse. (DN 4.9)

According to Democritus of Abdera, humans were first formed from water and mud. Epicurus is not far behind: he believed that at first 'wombs' of some kind grew in the heated mud, clinging to the roots of the earth; children were born out of these and the wombs offered them an organically occurring milky fluid, with nature's help. These original children, when grown and adult, propagated the human race. (trans. Parker)

The view that at least some living things were and are being generated spontaneously was a mainstream position in ancient natural philosophy. This is clear from the fact that Plato engages the position, as when he asks of plants and animals: 'does nature generate them by some spontaneous cause and grow them without thought, or are they generated by a god following reason and divine knowledge?' (Soph. 265c7-9; cf. Plt. 272a2-5, Leg. 10.889-890). Aristotle certainly held that several kinds of both plants and animals are generated spontaneously, ${ }^{27}$ and he gives the following kind of general explanation for the phenomenon.

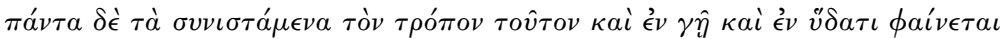

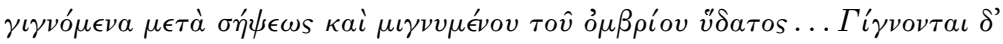

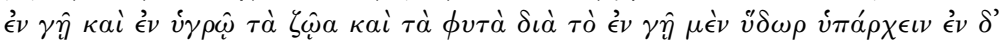

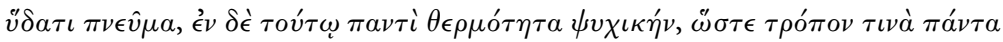

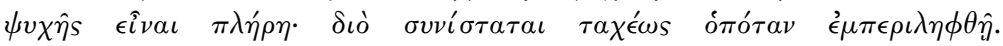

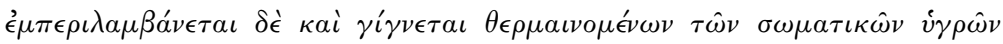

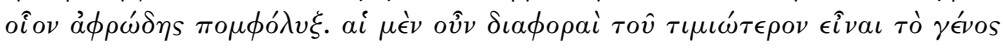

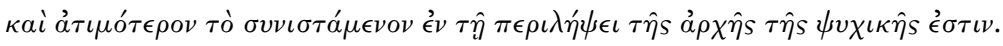

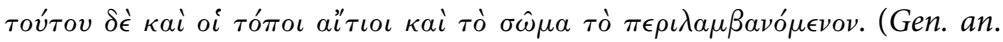
3.11.762a10-33)

All things formed in this way [sc. spontaneously generated], whether in earth or water, manifestly come into being in connection with putrefaction and admixture of rain-water... Animals and plants come into being in earth and liquid because there is water in earth, and air in water and in all air is vital heat so that in a sense all things are full of soul. Therefore living things form quickly whenever this air and vital heat are enclosed in anything. When they

27 Spontaneously generated are: plants (Gen. an. 715b27, Hist. an. 539a18); some animals (De an. 415a28, Gen. an. 743a35, 759a7, Hist. an. 539a22, b7, [Pr.] 898b5), specifically some insects (Hist. an. 551a1, Gen. an. 732b12, 758a30,b7), shellfish as a kind (Hist. an. 547b19, 548a11, Gen. an. 761a18-b26, 762a1-763a26), and some fishes (Hist. an. 539b3, 569a25, 570a16). 
are so enclosed, the corporeal liquids being heated, there arises a frothy bubble. Whether what is forming is to be more or less valuable in kind depends on the vital principle; and this depends on the medium in which the generation takes place and the corpora included. (trans. Platt, adapted)

In describing these generations as spontaneous, Aristotle is not at all arguing that they are causeless or indeterminate or random. In fact he goes into a striking amount of detail about the causes of spontaneously generated organisms. But Aristotle did not think, and in fact vigorously opposed the idea, that all animals could be generated spontaneously, and that all of the apparently purposeful adaptations of plants and animals could be accounted for by spontaneous causes. $^{28}$ In so doing he opposes widespread early Greek philosophical views, most prominently advocated by Democritus and Empedocles. Aristotle describes Empedocles as arguing that all the useful and advantageous adaptations of animals are due to a spontaneous cause in a passage that was destined to be cited by Charles Darwin in the first footnote to a historical introduction to The Origin of Species. ${ }^{29}$

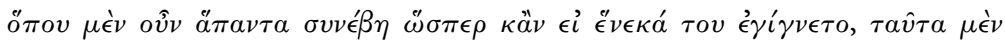

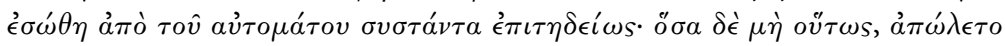

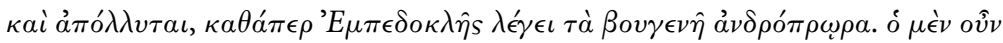

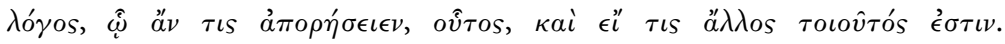
(Ph. 2.8.198b29-34)

Wherever they resulted as if happening for the sake of something, these things survived because they fittingly adapted due to spontaneity [àmò $\tau o \hat{v}$

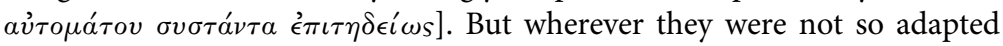
they perished and are perishing, just as Empedocles says the 'cow progeny with human faces' were. So this argument, and others like it if there are any, may present difficulties.

Lucretius, who is well versed in the arguments of both Democritus and Empedocles, takes a similar position to them, and in particular to Empedocles' idea of the extinction of unfit species, and the survival of those spontaneously well adapted.

${ }^{28}$ On the other hand, Aristotle does invoke spontaneity in describing various reproductive processes (Hist. an. 558a16, 559b1-6, 637b18, Gen. an. 749a35, 756a19) and deformities (Hist. an. 587b26, Gen. an. 773a18). Here his usage probably follows Democritus. Aristotle also uses the term 'automata' to describe devices like marionettes that model spontaneous animal motion (De motu an. 701b2-10, Gen. an. 734b9-17, 741b7-15; Metaph. 983a14).

29 'We see here the principle of natural selection shadowed forth' (Darwin 1861: n. 1). 
at quis nil horum tribuit natura, nec ipsa sponte sua possent ut uiuere nec dare nobis utilitatem aliquam quare pateremur eorum praesidio nostro pasci genus esseque tutum, scilicet haec aliis praedae lucroque iacebant indupedita suis fatalibus omnia uinclis, donec ad interitum genus id natura redegit. (Lucr. 5.871-7)

But those animals that nature endowed with none of these qualities, so that they were unable either to be self-supporting [sponte sua] or to render us any useful service, in return for which we might allow their kind to have sustenance and security under our protection, were of course an easy prey and prize for others, shackled as they all were by the bonds of their own destiny [fatalibus omnia uinclis], until nature brought their species to extinction. (trans. Smith)

Lucretius contrasts viable animals, who are able to survive spontaneously, with two groups: those that go extinct, on the one hand, and those, on the other hand, that are kept alive through an external cause-namely, domestication by humans. This again links the idea of spontaneous animal generation with that of spontaneous plant generation, which, as we have seen, is contrasted with artificial plant cultivation and agriculture. This distinction between spontaneous and cultivated generation of plants and animals is the ancient background of the distinction we now understand as natural versus artificial selection. ${ }^{30}$

We are by now very familiar with the project of extending the explanations of the natural selection of animals to the phenomena of human evolution and cultural development, and I think it is clear that Lucretius, following Democritus and Epicurus, was a pioneer in this field, and an immensely influential one. ${ }^{31}$ Lucretius extends the idea of creatures in nature struggling spontaneously for the sake of their

${ }^{30}$ Of course it must be emphasized that only a limited part of Darwin's theory of evolution was anticipated by these Democritean and Epicurean ideas, since the ancient atomists never accepted that any species could evolve, or, indeed, that parents could differ in kind from offspring in any essential way, as noted by Long (1977: 83); Campbell (2003) compares the ancient and modern theories in detail. Historical links between Lucretius and Darwin are also discussed in Johnson and Wilson (2007: 143).

31 This is a core project of naturalistic philosophy, and it is also reflected in the Epicurean effort to discover animalistic and non-rational counterparts to human emotions, as David Konstan argues, this volume, Chapter 7. 
own survival to the human condition, and to his account of our historical development. Lucretius describes the activities of humans in a primitive 'state of nature' as being spontaneous.

nec commune bonum poterant spectare neque ullis

moribus inter se scibant nec legibus uti.

quod cuique obtulerat praedae fortuna, ferebat

sponte sua sibi quisque ualere et uiuere doctus. (Lucr. 5.958-61)

They were unable to look to common interest, and had no knowledge of the mutual benefits of any customs or laws. Individuals instinctively seized whatever prize fortune had offered to them, for each was taught spontaneously to live and thrive for himself alone [sponte sua sibi quisque ualere et uiuere doctus]. (trans. Smith, adapted)

Individuals acting spontaneously act independently of the realm of laws and external constraints. The cause of their actions is their own nature; some drive internal to themselves, and neither any kind of instruction nor even consideration of other humans guides their action, resulting in the slightly paradoxical notion that early humans were spontaneously taught (doctus) by necessity itself. ${ }^{32}$

Lucretius holds that humans are able to do many things spontaneously, without instruction, art, laws, or even culture. Pliny argues, to the contrary, that humans are completely impotent in a state of nature, and are capable of nothing spontaneously: 'man is the only one that knows nothing, that can learn nothing without being taught; he can neither speak, nor walk, nor eat, and, in short, he can do nothing spontaneously at the prompting of nature [naturae sponte], but weep' (HN 7.1, trans. Bostock and Riley, adapted). Pliny refers to the vulnerability and nakedness of human beings at birth in a way that recalls the Great Speech of Protagoras in the dialogue by Plato wherein the title character is made to argue that human beings were naturally weak and on the brink of extinction before being granted laws and technology by the Gods. Lucretius offers an account (to a large extent probably following Epicurus) similar in part but also importantly different from this kind of account. Lucretius too describes the early condition of humans as being defenceless and

32 Bailey (1947) notes ad loc. 'sc. by necessity'. Plato frequently contrasts learning through instruction with spontaneously coming to understand something in a way that makes it clear that he does not think that humans can come to know much spontaneously (Alc. 118c3-4; cf. Euthphr. 282c2; Prt. 320a3, 323c6; Meno 93e8). 
nearly helpless. ${ }^{33}$ But he goes on to give a naturalistic account of how humans escaped from this condition that is explicitly opposed to the divine providence and command theory of Plato (and later the Stoics). Instead, the Epicurean account elaborates on the earlier and highly influential naturalistic account of Democritus. ${ }^{34}$

In line with this, Lucretius later describes humans as eventually moving beyond their narrow self-interest spontaneously, voluntarily submitting themselves to law.

nam genus humanum, defessum ui colere aeuom,

ex inimicitiis languebat; quo magis ipsum

sponte sua cecidit sub leges artaque iura. (Lucr. 5.1145-7)

The human race, utterly weary as it was of leading a life of violence and worn out with feuds, was the more ready to submit voluntarily [sponte sua] to the restraint of ordinances and stringent laws. (trans. Smith)

With this passage we return to an idea we first encountered in Xenocrates, who, when asked what his disciples learned, is said to have replied: 'to do spontaneously [sua sponte] what they are compelled to do by the law' (Rep. 1.2.3, trans. Keyes, adapted). Lucretius has to explain the spontaneous development of laws and customs, in order to avoid a divine-command-and-providence theory of the kind suggested by Plato's Protagoras in the Great Speech, or any of its relatives and descendants. Lucretius, following the naturalistic Democritean account (which may have been closer to what the historical Protagoras actually thought than what is put into his mouth by Plato), ${ }^{35}$ argues that humans 'voluntarily' submitted to laws, using the term 'spontaneously' to oppose the notion that this happened through external-that is, divine-imposition, constraint, or even instruction.

33 See Holmes, this volume, Chapter 6; and Konstan, this volume, Chapter 7.

34 Cole (1967/1990: 3-4, 10-13, 26-45-and for the Protagoras myth, see 50-1). Furley (1978/2007: 166) suggests that Epicurus' target is not only the naive view that the arts are gifts to humans from gods like Athena or Hermes, but also the position of Plato, Laws 10, according to which art is prior to nature; and the view probably represented in Aristotle's lost dialogue On Philosophy that civilization is periodically destroyed by floods and cataclysms so that the arts have to be built up from the wisdom preserved by the survivors.

35 This point is sustained by Havelock (1957: 87-103). 
Another use of 'spontaneously' to mean 'voluntarily' in Lucretius has him describing an individual human action. The individual happens to be Democritus.

denique Democritum post quam matura uetustas

admonuit memores motus languescere mentis,

sponte sua leto caput obuius obtulit ipse.

ipse Epicurus obit decurso lumine uitae,

qui genus humanum ingenio superauit et omnis

restinxit, stellas exortus ut aetherius sol. (Lucr. 3.1039-44)

Democritus, warned by ripe old age that the motions of his mind's memory were failing, voluntarily [sponte sua] went to meet death and offered him his life. Epicurus himself died, when the light of his life had accomplished its course-he who outshone the human race in genius and obscured the lustre of all as the rising of the ethereal sun extinguishes the stars. (trans. Smith)

The concept of spontaneity is often used in the context of death to indicate what we would call death by 'natural' causes, as opposed to violent ones. As I mentioned earlier, this usage relates to the ancient idea that both generation and destruction in nature are due to spontaneous causes. Plato, for example, has Socrates refer to death by natural processes: 'If you had waited a little while this would have happened from natural causes [apo tou automatou]. You see my age, that I am already advanced in years and close to death' (Ap. 38c5-6, trans. Grube; cf. Hdt. 2.66.4). Theophrastus also describes the death of plants by natural causes (as opposed to being cut down) as spontaneous: 'withering from old age and weakness is natural, when the tree dissipates its fluid and lets its heat die down spontaneously, whereas death coming from the outside is unnatural' (Caus. pl. 5.11.1.3-6, trans. Einarson and Link). In these uses we see the now familiar distinction between internal and external causes, nature and art.

But Lucretius is not referring to natural causes in describing Democritus' death in terms of spontaneity. Democritus' death may have been something like a suicide; we are told by Athenaeus that Democritus died by self-imposed starvation. ${ }^{36}$ It would be going too

\footnotetext{
36 Athenaeus writes: 'There is a story that Democritus of Abdera had decided to commit suicide because he was old, and was reducing the amount he ate every day. When Thesmophoria-time arrived, the women in his house asked him not to die during the festival, so that they could celebrate it. He agreed and told them to put a jar of honey beside him; and he lived the necessary number of days, getting all his energy
} 
far to translate sponte sua ... ipse as 'of his own free will' here (as does Rouse-Smith, for example), but no doubt what is meant is that Democritus, like Epicurus after him, was courageous in voluntarily meeting his death. It would seem that Lucretius cleverly alludes to the terminology of Democritus' own natural philosophy (and probably his political philosophy as well) by citing 'spontaneity' in this eulogy, so that the man who championed spontaneity as a cause in his cosmology and politics also died by the same cause, 'spontaneously'that is, voluntarily-giving up his life. ${ }^{37}$

The term spontaneity is used in archaic poetry to indicate voluntary action, where it is often translated 'of his own accord', as when Homer says: 'of his own accord [automatoi] Menelaos came to him' (Il. 2.408). ${ }^{38}$ This usage is also found in Aristophanes: 'Zeus is here; he came of his own accord [automatoi]' (Plut. 1190); and Eupolis: 'Good men go of their own accord [automatos] to a good man's party' (fr. 289 apud Plato, Symp. 174b4-5). Xenophon uses the term 'spontaneity' to convey the absence of compulsion: 'various speakers arose, some of their own accord [ek tou automatou] to express the opinions they held, but others at the instigation of Clearchus' (An. 1.3.13, trans. Brownson). A particularly vivid and important example of this usage is found in Plato, who has Socrates say in his defence speech that 'the young men who follow me around of their own free will [automatoi]...take pleasure in hearing people questioned' (Ap. 23c2-4, trans. Grube). Again, 'free will' is an excessive translation, if one considers 'the problem of free will' in the narrow technical sense; the exact problem as such emerged after Plato and Aristotle, and certainly after Socrates. ${ }^{39}$ But Socrates certainly could argue that he did not compel the youths to follow him around but they did it voluntarily or freely. This is the sense in which Lucretius says that Democritus went to his death 'spontaneously'.

from the honey. After the days were up and the honey was gone, he died' (2.46ef, trans. Olson = DK 68 A 29; cf. Diog. Laert. 9.43).

37 Bailey (1947: 1168), in his commentary on memores motus languescere mentis (Lucr. 5.1040), points out that this is 'a carefully chosen expression not only for its alliteration, but because it is couched in atomic terms: the memores motus are among the sensiferi motus'. To this we may add that sponte sua also recalls atomistic terms.

38 See also the commentary on this line by Demetrius of Phaleron apud Ath. 5.4, $177 \mathrm{c}-178 \mathrm{a}$.

39 See the persuasive and exacting studies of Bobzien $(1998,2000)$. 
Lucretius, too, was probably not concerned with something like the problem of free will, but rather the more traditional and, in a way, more fundamental problem of spontaneous and voluntary action. What I have said so far about the concept of spontaneity as a natural cause of voluntary actions, sharply differentiated from external force and coercion, will be the background for my interpretation of the much-discussed passage about voluntary action in book 2 .

denique si semper motus conectitur omnis et uetere exoritur motu nouus ordine certo nec declinando faciunt primordia motus principium quoddam quod fati foedera rumpat, ex infinito ne causam causa sequatur, libera per terras unde haec animantibus exstat, unde est haec, inquam, fatis auolsa uoluntas per quam progredimur quo ducit quemque uoluptas, declinamus item motus nec tempore certo nec regione loci certa, sed ubi ipsa tulit mens? nam dubio procul his rebus sua cuique uoluntas principium dat et hinc motus per membra rigantur. nonne uides etiam patefactis tempore puncto carceribus non posse tamen prorumpere equorum uim cupidam tam de subito quam mens auet ipsa? omnis enim totum per corpus materiai copia conciri debet, concita per artus omnis ut studium mentis conixa sequatur; ut uideas initum motus a corde creari ex animique uoluntate id procedere primum, inde dari porro per totum corpus et artus. nec similest ut cum impulsi procedimus ictu uiribus alterius magnis magnoque coactu; nam tum materiem totius corporis omnem perspicuumst nobis inuitis ire rapique, donec eam refrenauit per membra uoluntas. iamne uides igitur, quamquam uis extera multos pellat et inuitos cogat procedere saepe praecipitesque rapi, tamen esse in pectore nostro quiddam quod contra pugnare obstareque possit? cuius ad arbitrium quoque copia materiai cogitur interdum flecti per membra per artus et proiecta refrenatur retroque residit. 
quare in seminibus quoque idem fateare necessest, esse aliam praeter plagas et pondera causam motibus, unde haec est nobis innata potestas, de nilo quoniam fieri nil posse uidemus. pondus enim prohibet ne plagis omnia fiant externa quasi ui; sed ne mens ipsa necessum intestinum habeat cunctis in rebus agendis et deuicta quasi cogatur ferre patique, id facit exiguum clinamen principiorum nec regione loci certa nec tempore certo. (Lucr. 2.251-93)

If all movements are invariably interlinked, if new movement arises from the old in unalterable succession, if there is no declinando to initiate movement that can annul the decrees of destiny [fati foedera] and prevent the existence of an endless chain of causation, what is the source of this liberty [libera] possessed by living creatures all over the earth? What, I ask, is the source of this power of voluntary will [uoluntas] wrested from destiny [fatis], which enables each of us to advance where pleasure leads us, and to alter our movements not at a fixed time or place, but at the direction of our own minds? For undoubtedly in each case it is the voluntary will [sua cuique uoluntas] that gives the initial impulse to such actions and channels the movements through the limbs.

Have you not observed too that, at the very moment when the starting gates are opened, the horses, despite their strength and impatience, cannot burst forward as suddenly as their minds desire? The reason is that the whole mass of matter throughout the body must be actuated: only when the whole frame has been actuated can it respond with energy to the eagerness of the mind. So you can see that the initial movement is produced by the mind: it originates from the act of mental will, and is then diffused through every part of the body.

But it is a quite different matter when we are thrust forward by a blow delivered from a formidable force and powerful pressure by another person; for in that event it is transparently clear that the whole bulk of our body moves and is swept along involuntarily until the will has reined back all our limbs. So do you now see that, even though an external force [uis extera] pushes a crowd of us, often compelling us to move forward against our will and sweeping us along precipitately, there is in our breasts something with the ability and the will to oppose and resist it? At its bidding the mass of matter through every member and limb at times is compelled to change direction or, when thrown forward, is reined back and brought back to rest. 
Thus you are obliged to acknowledge that the seeds have the same ability, and that, besides blows and weight, they have another cause of motion from which this innate power of ours is derived, since we see that nothing can come into being from nothing. Weight ensures that all movements are not caused by blows-that is to say by external force [externa quasi ui]. But the factor that saves mind itself from being governed in all its actions by an internal necessity [necessum intestinum], and from being constrained to submit passively to its domination, is the minute swerving [clinamen] at unpredictable places and times. (trans. Smith, adapted)

I take Lucretius to be referring to two of the causes applicable to atomic motion identified by Democritus: ${ }^{40}(1)$ the spontaneous and natural motion of the atoms in the void, downwards, in accordance with its own inner necessity, determined by weight or gravity; (2) the externally imposed modification of downwards motion inflicted by 'blows' or 'impacts' or 'collisions' of material bodies with other material bodies. To this Lucretius adds a third cause of motion, which, he stresses, is free from both external forces and internal necessity.

Although Lucretius stipulates that this 'deviation' or 'swerve' occurs 'not at a fixed time or place' and 'at unpredictable places and times', there is no reason to think that this motion is random, chance, purely contingent, and so forth. For we have repeatedly seen how Lucretius has described natural bodies, including those of plants and animals, to be in accordance with certain laws spontaneously, not as a result of external force or necessitation. I think that, in the present passage, Lucretius is extending this notion to individual human behaviour, just as he later extends it to collective human behaviour in his discussion of 'spontaneous' submission to laws and restraints, and even to individual human behaviour with his description of Democritus on his deathbed.

Smith's translation 'free will' for libera in the passage just discussed will not do, for the reasons mentioned above, ${ }^{41}$ and because Smith also translates uoluntas as 'will', even though that term is not cognate with libera. Further, it is not usual to speak of 'free will' in connection with animal motion, except for human motion. But Lucretius is here talking about animal motion in general, of 'creatures all over the 
earth'. His main example, in 2.263-71, is strikingly not of human action, but of a horse starting out of a gate. This is because, again, Lucretius here is not concerned with 'the free will problem', but rather with the problem of how an animal can initiate its own motion even so as to oppose external forces. This he makes clear with the repeated reference to 'external force' (uis extera, 277, 289). The horse is said to initiate motion throughout its body by an act of mental will that is materially transmitted to the animal's limbs. This is opposed to an animal being forced to move by blows or pressure, as when a horse is ridden, or we are swept up in a crowd and moved along even against our will. Thus the contrast Lucretius draws is explicitly between an internal and an external cause of motion, and it is argued that at least some animals, such as horses, have an internal cause of motion. It is remarkable that Aristotle in Physics 2 gives the same example of the cause of spontaneity: 'the spontaneous is found in the beasts and in many inanimate objects. We say, for example, that the horse came spontaneously, because, though his coming saved him, he did not come for the sake of safety' (197b13-17). According to Aristotle, the horse moved spontaneously (and not by force) because the cause of its motion was internal to the horse, even though the horse did not do so for the sake of being saved. Thus there is a traditional background against which Lucretius conceives of an animal such as a horse moving 'spontaneously' when it initiates its own motion. Spontaneity is the positive notion required here by the denial of external and extrinsic causes totally determining animal motion.

I propose that we should understand the declinando to initiate movement that can annul the decrees of destiny (fati foedera) and prevent the existence of an endless chain of causation' in 253-4 to be spontaneous, but not random, contingent, or indeterminate. The 'declination' is opposed to something caused or moved by external forces, 'decrees of destiny', and it is not at all opposed to what has a cause or gives signs of orderly, determinate, even intentional action. On the contrary, this is exactly what it is meant to explain: the appearance of free and independent and natural activity on the part of animals and human beings. Lucretius holds that humans, including the savages who eventually voluntarily subjected themselves to laws, and even Democritus himself, acted spontaneously, following their own nature, just as all the other natural bodies, animals, plants, celestial bodies, the elements, and atoms, move and are generated 
and destroyed spontaneously. In this sense the causes and seeds of the voluntary motions of horses and humans are the same, and are tightly tied to their natures and desires.

It is very clear, however, that Lucretius intends to make a point not just about the 'voluntary' motions of beasts, but about human 'liberty' and 'voluntary will', and this is why he makes reference to an ability 'which enables each of us to advance where pleasure leads us, and to alter our movements not at a fixed time or place, but at the direction of our own minds' and asserts that 'there is in our breasts something with the ability and the will to oppose and resist' external forces and causes. He opposes this ability both to external force and to internal necessity' but associates it with the voluntary will. A passage in Cicero describes the interrelation of these concepts.

si imprudenter aut necessitate aut casu quippiam fecerit quod non concederetur eis qui sua sponte et uoluntate fecissent, ad eius facti deprecationem ignoscendi petenda uenia est quae sumetur ex plerisque locis aequitatis. (Part. or. 37.131)

If someone has carelessly or under compulsion [necessitate] or by accident [casu] done that which would not be permissible for those who had acted spontaneously [sua sponte] and voluntarily [uoluntate], in order to plead forgiveness for that action pardon must be sought which is taken from many topics of equity. (Cf. Pro Scauro 41; Sen. 71)

Cicero's account of the legal terminology thus associates the spontaneous and the voluntary, and opposes these to things done under compulsion or by accident ('against one's will', one is tempted to say). This fits perfectly with Lucretius' terminology. The power for voluntary actions that he takes a stand in defending is a power that opposes external force, coercion, and necessitation, and is thus spontaneous. It is, further, opposed to the merely accidental (casu).

It is thus not necessary to assume, as has often been done, that, by embracing spontaneity in the case of voluntary action, Lucretius is forced to admit pure contingency, accident, randomness, or chance into his cosmology or account of voluntary action. ${ }^{42}$ On the contrary,

42 See, e.g., Guyau (1878: 72-102); followed, e.g., by Rist (1972: 52), who speaks of 'a random element, an element of chance in nature'. Bailey (1928: 326) admits 'real contingency in nature, an element of chance'; cf. Bailey (1947: 840). See Long (1977: 65-6) for a thoroughgoing and convincing refutation of these interpretations. 
in the context of voluntary human action, the spontaneous is as opposed to the accidental and contingent as it is to external force and coercion. Philosophically, this is a very good thing, since mere physical 'indeterminacy' is as much a threat as a panacea to responsibility and voluntary rational action. 